\title{
Time-varying parameters of Croatian import demand*
}

\author{
Mile Bošnjak ${ }^{1}$ Vlatka Bilas ${ }^{2}$, Domagoj Račić ${ }^{3}$
}

\begin{abstract}
The paper aims to examine Croatian import demand elasticities to changes in income and relative prices while allowing time variation in parameters of import demand. Data sample consist of quarterly time series data over the period 2000 q1 -2018 q3. Following state space model with time-varying parameters approach estimates were obtained and tested. The results revealed persistent and high income elasticity of import demand in Croatia. However, the role of relative prices has changed over the observed period and eventually cannot be distinguished from zero. The findings from this research supported the hypothesis of prices convergence in Croatia towards the prices within European Monetary Union member countries. Furthermore, results found no significant effect on Croatian import demand when Croatia joined the European Union. The research results indicate that, due to a relatively high income elasticity of import demand and convergence of import prices, production of innovative and sophisticated products should be facilitated.
\end{abstract}

Key words: import demand, income, relative prices, Kalman filter, Croatia

JEL classification: $C 13$, C51, F17, F14

\footnotetext{
* Received: 01-06-2019; accepted: 18-12-2019

${ }^{1}$ Assistant Professor, University of Zagreb, Faculty of Economics and Business, JF Kennedy Square 6, 10000 Zagreb, Croatia. Scientific affiliation: international economics, nonlinear econometrics, applied econometrics, neural networks. Phone: +38512330 374. E-mail: mbosnjak1@net.efzg.hr.Website: https://orcid.org/0000-0002-7663-198X.

2 Full Professor, University of Zagreb, Faculty of Economics and Business, JF Kennedy Square 6, 10000 Zagreb, Croatia. Scientific affiliation: international economics, regional economic integration.Phone: +3851 2330374.E-mail:vbilas@efzg.hr.Website: https://orcid.org/00000002-9021-6651.

${ }^{3}$ PhD Candidate, J.J. Strossmayer University of Osijek, Faculty of Economics in Osijek, LJ. Gaj sq. 7, 31000 Osijek, Croatia. Scientific affiliation: innovation, competitiveness, political economy. E-mail:domagoj.racic@mrezaznanja.hr.Website: https://orcid.org/0000-0001-8380-9996.
} 


\section{Introduction}

In the last three decades, Croatia has experienced transition from a socialist towards a market economy, accompanied with liberalization of international trade and capital flows along with persistent current account deficit. While previous studies have directed its attention towards current account determinants (Bošnjak et al. 2018), its sustainability (Bošnjak et al. 2019) and exports (Bogdan et al., 2017), not much attention has been directed towards elasticity of substitution between domestic and foreign goods. In 2013 Croatia joined the European Union (EU) and became more integrated within the EU economy. Elasticity of substitution between domestic and foreign goods is one of the focal issues in international economics and an important topic for any economy. Therefore, the paper brings elasticity of import demand function in Croatia. The topic of import demand elasticity is not a new one. However, development of new econometric approaches enables us to shed light on the old topic.

Furthermore, and as already mentioned, Croatia passed various stages from a socialist to market economy and determinants of import demand may have varied over time. Consequently, besides traditional time series - regression approach with ordinary least square estimates, the paper employs state space model with time varying parameters approach to provide more insightful results revealing dynamics of the elasticity over time. Since joining the European Monetary Union (EMU) is the next step of Croatia's integration process, the special attention of this paper is directed towards convergence of prices between Croatia and EMU members. Therefore, the paper aims to examine time variation in Croatian import demand elasticity. The goal of the paper is to estimate import demand elasticity using different econometric approaches. In line with the aim and the goal and the special attention of the paper, the research hypothesis of this paper assumes convergence of prices between Croatia and EMU members.

The remainder of this paper is organized as follows: Section 2 briefly summarizes existing literature related to the topic under consideration. Section 3 presents methodology, while Section 4 provides data and empirical analysis. Section 5 research results and discussion and final section provides an overview of the main findings of the research.

\section{Brief literature overview}

Based on the model of imperfect substitutes (Mervar, 1994), import demand function of a country can be represented in equation (1):

$$
I M=f\left(Y_{-} d, P_{-} d, P_{-} I M\right)
$$


Therefore, import demand of a country (IM) is expected to be determined with domestic income ( $\mathrm{Y}$ d), domestic prices of imperfect substitutes at home market $\left(\mathrm{P} \_\mathrm{d}\right)$ and price of imported goods (P_IM). The effects of an increase in domestic income and domestic prices of imperfect substitutes are expected to be positive while the effect of increase in price of imported goods is expected to be negative. Following a form of baseline specification, empirical literature from all over the globe has pointed in many directions. Crucini and Davis (2016) point out the role of distribution capital. In case of a slow adjustment of capital distribution, the agents cannot shift demand towards lower price in response to price changes in a short run. Following capital reallocation, the demand will be shifted only in the long run. Following Crucini and Davis (2016), domestic and foreign goods are poor substitutes in the short run, while in the long run, the substitutability increases. One strand of literature is directed towards long run while other examines short run import demand function and elasticity of substitution. Zhang et al. (2017) examined the long run import demand elasticity for China. Kurtovic et al. (2016) examined elasticity of international trade of Bosnia and Herzegovina against its seven trading partners, including Croatia. The results found income and price elasticity of the trade flows and revealed $\mathrm{J}$ curve pattern in effects from prices to net exports. Auboin and Borino (2018) dealt with slowdown in growth of global trade and estimated the import demand elasticity for 38 advanced and developing countries over the period 1995-2015. Recent paper from Çulha et al. (2019) employed the state space model with time varying parameters to examine the case of Turkey and found short term import demand elastic to changes in income and relative prices. Furthermore, the income elasticity of import demand was found to be higher compared to price elasticity in the case of Turkey. Ghodsi et al. (2016) examined import demand elasticity for 167 countries and found the highest average elasticity of import demand within the most important countries from the economic perspective. Furthermore, the lowest import demand elasticity was reported for small island states. The illustrated papers show vitality of the baseline theory and its suitability to illustrate contemporary state in the economy over the globe. Besides the one from Mervar (1994), the literature has not dealt explicitly with import demand substitution in Croatia neither with convergence of prices toward other EU member countries. Mervar (1994) examined Croatian import demand on a monthly data sample from January 1990 to December 1993 and provided the results at the early stage of trade and financial liberalization process. However, some facts from research based on various theories of international economics might be relevant for the topic under consideration. Bilas and Bošnjak (2015) found international trade between Croatia and other European Union member countries in line with Heckscher-Ohlin trade theorem while Croatia was a labour abundant country. Following Bošnjak et al. (2018), the current account in case of Croatia was under pressure of domestic demand with modest effects out of real effective exchange rate. Bošnjak et al. (2019) and Bošnjak (2019a) found unsustainable merchandise trade flows between Croatia and other EU member countries pointing out ineffective 
macroeconomic policies in Croatia. Ranilović (2017) followed standard gravity model and found positive effects of the Croatia's accession to the European Union on its trade. Furthermore, and in line with the gravity approach, Croatia was found to be trading more with higher income and closer countries as well as with the countries of former Yugoslavia. Mikulić and Lovrinčević (2018) examined import content across economic sectors in Croatia and found the highest import content of domestic final demand for exports and gross fixed capital formation while pointing out low import dependence in Croatia that was more similar to the results of larger self-sufficient economies. Therefore, Croatian imports seem to be mostly driven by domestic demand. Buturac et al. (2019) found a substantially improved export performance of the Croatian manufacturing industry after EU accession of Croatia. However, recalling the baseline theory formulated in equation (1) there is a role of difference in foreign and domestic prices in substitution between home and foreign goods. As long as Croatia becomes more integrated into the EU economy, it is expected that prices in Croatia converge towards EU prices. Cerasa and Buscaglia (2017) examined price convergence within the European Union coffee market and the results did not support hypothesis of price convergence and deepening of the European market integration. Hałka and Leszczyńska-Paczesna (2019) analysed price convergence in the European Union countries in the period 1999-2016 and found significantly lower dispersion in 2016 compared to 1999, indicating catchingup of countries with price level below the average that was more prominent up until 2008. This paper contributes to the discussion with empirical results from Croatia. Furthermore, elasticity of substitution between domestic and foreign goods is one of the focal points in the international economics, contributing to understanding drivers of imports and shaping macroeconomic policy of the economy. As already stated, there is no contemporary literature dealing with elasticity of import demand in Croatia and its case might be interesting due to the dynamic path Croatia experienced in the last two decades during its process of integration with the EU countries. Therefore, there is a literature gap and by bringing accurate and robust estimates of import demand elasticity from state space model with time varying parameters this paper makes a step ahead.

\section{Methodology}

The paper firstly follows the conventional approach that starts with testing of unit root in the observed series. The unit root tests are well known for its low power. Therefore, to improve the validity of the results, paper employs several different unit root tests. Namely, Augmented Dickey-Fuller (1979) (ADF test), PhillipsPerron (1988) (PP test), the Generalized Least Squares and Dickey-Fuller test (DF-GLS test) that is developed by Elliot et al. (1996), Kwiatkowski et al. (1992) (KPSS test). Therefore, after unit root testing for each of the observed series, Engle and Granger (1987) cointegration test was performed. With respect to unit 
root tests results and results of cointegration test, the estimates were obtained from regression analysis of time series and corresponding diagnostics were performed. Furthermore, constancy of parameters was tested as suggested by Andrews (1993) and Andrews and Ploberger (1994). Following Andrews (1993) and Andrews and Ploberger (1994), decision on parameter constancy is based on test statistic from equation (1.1):

$$
\exp F=\log \left(\frac{1}{\bar{\imath}-\underline{i}+1} \sum_{i=\underline{i}}^{\bar{\imath}} \exp \left(0.5 \cdot F_{i}\right)\right.
$$

After providing the results from regression time series approach, the paper employs a state space model with time-varying parameters with starting values obtained with ordinary least square (OLS) estimates and regression time series approach. Modelling the import demand elasticity within TVP framework allows us the insights into evolution of the relationship with the time that is speciously suitable in this case since Croatia joined the EU within the observed period and has experienced a deepening of economic integration with the EU. Recent empirical papers recognized advantages of estimates from states space model with time varying parameters approach over conventional time series approaches. Bošnjak (2019) fitted the state space model with time varying parameters to illustrate determinants of current account in cases of Serbia and Romania and Çulha et al. (2019) employed the state space model with time varying parameters to examine import demand elasticity in the case of Turkey. Following Harvey (1991), a general form of the state space model is presented in observation (2) and transition equation (3).

$$
\begin{aligned}
& \Delta Y_{t}=\Delta X_{t} \beta_{t}+\varepsilon_{t}, \varepsilon_{t} \sim \operatorname{IIDN}\left(0, \sigma^{2}\right), \\
& \beta_{t}=\theta+\Gamma \beta_{t-1}+v_{t}, v_{1, t} \sim \operatorname{IIDN}(0, Q), E\left(e_{t} V_{s}\right)=0,
\end{aligned}
$$

Where:

$Y_{t}-1 \times 1$ vector presenting observed dependent variable,

$X_{t}-\mathrm{k} \times 1$ vector presenting observed explanatory variables,

$\beta_{t}-\mathrm{k} \times 1$ vector presenting unobserved variables,

$\Gamma-\mathrm{k} \times \mathrm{k}$ matrix of constant parameters,

$\varepsilon_{t}-$ error term in observation equation (1),

$v_{t}-$ error term in transition equation (1) and

$Q$ - the diagonal variance-covariance matrix. 
Kalman (1960) provided the algorithm to obtain filtered and smoothed estimates of unobserved time-varying coefficients $\left(\beta_{t}\right)$ recursively. The prediction equation is given in the equation (4) and the covariance matrix is given in the equation (5).

$$
\begin{aligned}
& \hat{\beta}_{t \mid t-1}=T \hat{\beta}_{t-1} \\
& P_{t \mid t-1}=T P_{t-1} T^{\prime}+Q_{t}
\end{aligned}
$$

Eventually, the estimates were updated recursively following equations (6) and (7).

$$
\begin{aligned}
& \hat{\beta}_{t}=\beta_{t \mid t-1}+P_{t \mid t-1} X\left(Y_{t}-X^{\prime} \hat{\beta}_{t \mid t-1}\right)\left(X P_{t \mid t-1} X+H_{t}\right) \\
& P_{t}=P_{t \mid t-1}-P_{t \mid t-1} X^{\prime} X P^{\prime}{ }_{t \mid t-1} /\left(X^{\prime} P_{t \mid t-1} X+H_{t}\right)
\end{aligned}
$$

A time-varying parameters (TVP) within state space model consists of an observation or measurement equation and a transition or state equation. Thus, the import demand equation in case of Croatia can be specified in logarithmic form given by the equations (8) to (12):

$$
\begin{aligned}
& \Delta \ln \left(M_{t}\right)=\alpha_{t}+\beta_{1, t} \Delta \ln \left(Y_{t}\right)+\beta_{2, t} \Delta \ln \left(\operatorname{REER}_{t}\right)+ \\
& +\beta_{3, t} \mathrm{EU}+\varepsilon_{t}, \quad \varepsilon_{t} \sim \operatorname{IIDN}\left(0, \sigma^{2}\right) \\
& \alpha_{t}=\alpha_{t-1}+v_{0, t}, v_{1, t} \sim \operatorname{IIDN}\left(0, \sigma_{v 0}^{2}\right) \\
& \beta_{1, t}=\beta_{1, t-1}+v_{1, t}, v_{1, t} \sim \operatorname{IIDN}\left(0, \sigma_{v 1}^{2}\right) \\
& \beta_{2, t}=\beta_{2, t-1}+v_{2, t}, v_{2, t} \sim \operatorname{IIDN}\left(0, \sigma_{v 2}^{2}\right) \\
& \beta_{3, t}=\beta_{3, t-1}+v_{3, t}, v_{3, t} \sim \operatorname{IIDN}\left(0, \sigma_{v 3}^{2}\right)
\end{aligned}
$$

Where the observation equation is given by equation (8) and state equations by equations (9), (10), (11) and (12). State equations illustrate that the new state value is modelled as a linear combination of the former state value and an error process. The observation equation presents a relationship between observed variables and unobserved transition or state variables. Dependent variable $\Delta \ln \left(M_{t}\right)$ is observed and presents change in (natural) logarithmic value of imports $\left(M_{t}\right)$, while explanatory variables are changes in (natural) logarithmic value of GDP $\left(Y_{t}\right)-\Delta\left(Y_{t}\right)$, changes in (natural) logarithmic value of real effective exchange rate $\left(\mathrm{REER}_{\mathrm{t}}\right)-\left(\triangle \mathrm{REER}_{\mathrm{t}}\right)$ in (natural) logarithmic form and dummy variable (EU) that indicate EU membership. The explanatory variables establish the relationship between the observable dependent variable and the unobservable time-varying coefficients. The terms $\alpha_{t}$, $\beta_{1 t}, \beta_{2 t}$ and $\beta_{3 t}$ are unobserved time-varying coefficients to be estimated. $\varepsilon_{t}$ and $v_{0, t}$ 
represent the error term in the measurement and state equations, respectively. The model in equations (8), (9), (10), (11) and (12) presents a state space form with initial conditions. The estimates of the state space were obtained using the Kalman filter while the estimates of the parameters in the equations were obtained by maximizing the Likelihood-function. Kalman filter is a recursive procedure that needs to set plausible initial values. To do so, the parameters of the model were first estimated by means of OLS and these parameters and fitted values of the state variables obtained from the OLS estimation were specified as initial values. Eventually, the paper follows methodology presented in this section and brings the results for Croatian import demand elasticity. TVP approach allows the insight into time variation. Therefore, it is expected to illustrate potential convergence of prices within the EU and effects of the EU membership.

\section{Data and empirical analysis}

The research data sample consists of quarterly time series data over the period $2000 \mathrm{q} 1-2018 \mathrm{q} 3$. The data on imports and gross domestic product at constant prices were retrieved from the Croatian Bureau of Statistics. The data on real effective exchange rate against 19 European Monetary Union (EMU) countries was retrieved from the Eurostat database. All of the variables under consideration were $\mathrm{X}-13$ ARIMA seasonally adjusted and are transformed to (natural) logarithm so as to the estimated coefficients can be interpreted as elasticity. The observed series are illustrated in Figure A1 in the Appendix and descriptive statistics is provided in Table A1 in the Appendix. Imports from the EU to Croatia amounted to more than $78 \%$ of total imports and the main trading partners (Germany, Italy, Slovenia and Austria) are EMU member countries ${ }^{4}$. Furthermore, after 2010, share of imports to GDP in Croatia has constantly increased (see Figure A2 in the appendix). Following the methodology outlined above, Table 1 presents the results from standard unit root tests results.

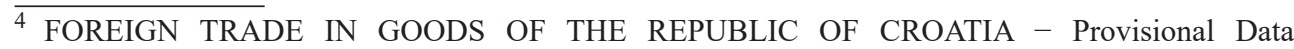
January - December 2018 and January 2019; available at: https://www.dzs.hr/Hrv_Eng/ publication/2018/04-02-01_12_2018.htm. 
Table 1: Unit root test results

\begin{tabular}{|l|c|c|c|c|}
\hline \multirow{2}{*}{ Variable and test } & \multicolumn{2}{|c|}{ Levels } & \multicolumn{2}{c|}{ First difference } \\
\cline { 2 - 5 } & Constant & $\begin{array}{c}\text { Constant and } \\
\text { trend }\end{array}$ & Constant & $\begin{array}{c}\text { Constant and } \\
\text { trend }\end{array}$ \\
\hline ADF test & \multicolumn{4}{|c|}{ t-stat. } \\
\hline $\log (Y)$ & -3.387478 & -2.156521 & -2.406368 & -4.486778 \\
\hline $\log (M)$ & -3.432169 & -3.104063 & -6.837247 & -7.118974 \\
\hline $\log ($ REER $)$ & -2.939482 & -2.254231 & -7.792558 & -8.097436 \\
\hline PP test & \multicolumn{4}{|c|}{ Adj. t-stat. } \\
\hline $\log (Y)$ & -4.204908 & -1.919389 & -3.320877 & -4.555013 \\
\hline $\log (M)$ & -3.012525 & -2.943056 & -7.064539 & -7.347781 \\
\hline $\log ($ REER $)$ & -2.890949 & -2.304949 & -7.794939 & -8.095229 \\
\hline DF-GLS & \multicolumn{4}{|c|}{ Adj. t-stat. } \\
\hline $\log (Y)$ & 0.251691 & -1.146336 & -2.156897 & -4.479584 \\
\hline $\log (M)$ & 1.446123 & -1.083567 & -6.783008 & -7.147429 \\
\hline $\log ($ REER $)$ & -0.330107 & -1.226741 & -7.796069 & -8.045666 \\
\hline KPSS test & \multicolumn{5}{|c|}{ LM-stat. } \\
\hline $\log (Y)$ & 1.022173 & 0.278919 & 0.693850 & 0.186800 \\
\hline $\log (M)$ & 0.932814 & 0.180218 & 0.353583 & 0.206388 \\
\hline $\log ($ REER $)$ & 0.725328 & 0.252688 & 0.322839 & 0.063843 \\
\hline
\end{tabular}

Source: Authors' calculations

Following standard unit root test results, the observed series were found to be integrated of order one I(1) while not cointegrated (Table 2 in Appendix). Consistently, the values of (natural) variables in first differences were examined and estimates of short-term effects are summarized in Table 2. 
Table 2: Estimates (OLS) of import demand: the case of Croatia

\begin{tabular}{|l|c|c|c|c|}
\hline & $\begin{array}{c}\text { Coeff. } \\
\text { Estimates }\end{array}$ & Root MSE & z-statistic & p-value \\
\hline$\alpha$ (Constant) & -0.006046 & 0.005591 & -1.081 & 0.2832 \\
\hline$\Delta \ln (Y)$ (Income) & 1.607558 & 0.323333 & 4.972 & $4.54 \mathrm{e}-06$ \\
\hline $\begin{array}{l}\Delta \ln (\text { REER) (Real effective } \\
\text { exchange rate) }\end{array}$ & 0.698453 & 0.363276 & 1.923 & 0.0586 \\
\hline $\begin{array}{l}\text { EU (EU membership - dummy } \\
\text { variable) }\end{array}$ & 0.009991 & 0.007495 & 1.333 & 0.1868 \\
\hline Adjusted R- squared: 0.2846 & F-statistic: 10.68 & p-value: $7.26 \mathrm{e}-06$ \\
\hline Diagnostic tests: & p-value: 0.1103 \\
\hline Ljung- Box Test statistic: 18.182 & p-value: 0.8121 \\
\hline Jarque Bera Test statistic: 0.41617 & p-value: 0.9048 \\
\hline ARCH Test statistic: 6.2169 &
\end{tabular}

Source: Authors' calculations

The results in Table 2 illustrate a relatively high and statistically significant average income elasticity of Croatian import demand. The average effects from real effective exchange rate deprivation were significant. Since the observed effects are short term, the estimate of real effective exchange rate on import demand is theoretically consistent. Domestic demand could hardly be redirected towards home products in a short run due to real exchange rate depreciation. Therefore, the real effective exchange rate depreciation can only change the prices of imported goods denominated in the domestic currency. Mervar (1994) found that change in the index of real effective exchange rate of one per cent implied the decrease of imports value by 0.45 per cent and comparison might be interesting. The results in Table 2 reveal no significant increase of import demand as a result of Croatia joining the EU. Eventually, diagnostic tests illustrate no misspecification and the estimates in Table 2 can be considered as valid estimates of income and price elasticity of the Croatian import demand. However, following Andrews (1993) and Andrews and Ploberger (1994) the constancy of parameters in linear regression model was tested and presented in Table 2 and p-values of the test are presented in Figure 1. 
Figure 1: p-values from Andrews (1993) and Andrews and Ploberger (1994) constancy test

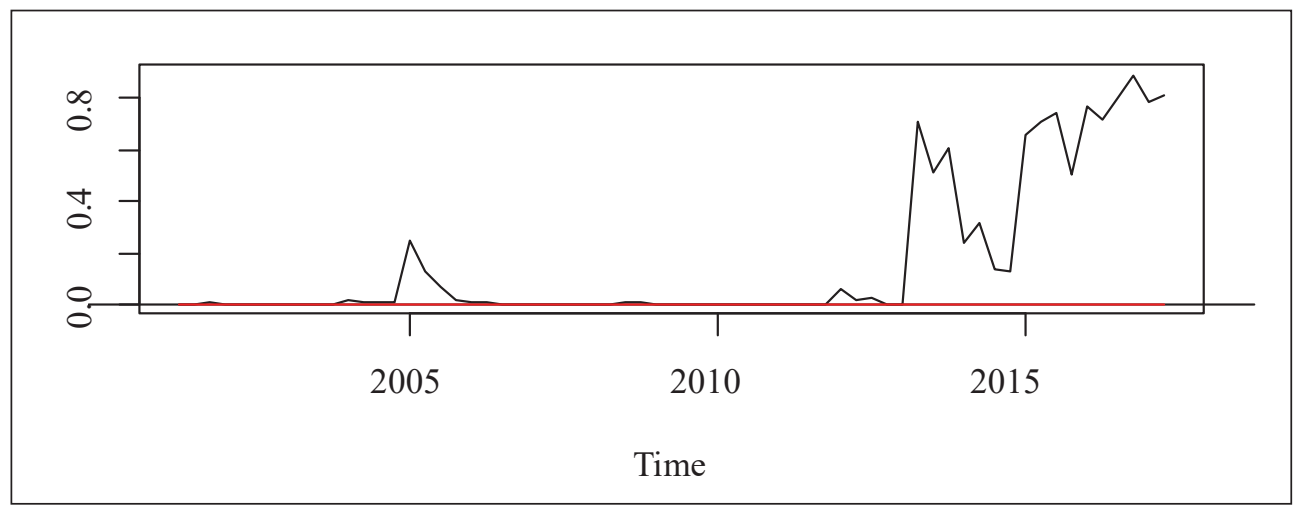

Source: own estimates

Table 3: expF statistic and corresponding p-value

\begin{tabular}{|c|c|}
\hline Test statistic (exp.F) & p-value \\
\hline 6.0155 & 0.02337 \\
\hline
\end{tabular}

Source: Authors' calculations

The results in Table 3 reject the null hypothesis of constancy in parameters of linear regression model. Consequently, the effects might be varying over the observed period. Therefore, as illustrated in the methodological section of the paper, state space model with time-varying parameters (TVP) was estimated while taking the estimates in Table 2 as the initial values. The results are presented in Table 4. 
Table 4: Time varying determinants of import demand: the case of Croatia

\begin{tabular}{|c|c|c|c|c|}
\hline & Final state & Root MSE & Z-statistic & $\mathrm{p}$-value \\
\hline$\alpha$ (Constant) & 0.0063746618 & 0.017486078 & 0,364556409 & 0.3577213 \\
\hline$\Delta \ln (\mathrm{Y})($ Income $)$ & 1.78298 & 0.4279295 & 4,16652743 & 0.0000155 \\
\hline $\begin{array}{l}\Delta \ln (\text { REER) (Real effective } \\
\text { exchange rate) }\end{array}$ & 0.2907273 & 0.8352686 & 0,348064443 & 0.3638959 \\
\hline $\begin{array}{l}\text { EU (EU membership - } \\
\text { dummy variable) }\end{array}$ & -0.004396363 & 0.01469020 & $-0,299271827$ & 0.3823663 \\
\hline \multicolumn{2}{|c|}{ Log likelihood: -186.9021} & \multicolumn{3}{|c|}{ AIC: -355.8042} \\
\hline \multicolumn{5}{|c|}{ Diagnostic tests: } \\
\hline \multicolumn{2}{|c|}{ Ljung- Box Test statistic: 14.472} & \multicolumn{3}{|c|}{ p-value: 0.2716} \\
\hline \multicolumn{2}{|c|}{ Jarque Bera Test statistic: 7.3248} & \multicolumn{3}{|c|}{ p-value: 0.02567} \\
\hline \multicolumn{2}{|l|}{ ARCH Test statistic: 4.8232} & \multicolumn{3}{|c|}{ p-value: 0.9636} \\
\hline
\end{tabular}

Source: Authors' calculations

The results in Table 4 present the estimates in final states. Short-term income elasticity of the Croatian import demand is very close to the one shown in Table 2 that was obtained using OLS as an estimator. Furthermore, Figure A4 in the Appendix illustrates the constancy of income elasticity of import demand during the observed period. Results that are more interesting are obtained for price elasticity illustrated in Figure A5 in the appendix. Following the results in Table 4 at the final state Croatian import demand is inelastic to change in prices since the effect was not statistically distinguishable from zero. Figure A5 illustrates time variation in price elasticity of the Croatian import demand. At the beginning of the observation period, the price elasticity of the Croatian demand was above unity and by the time it has approached zero.

\section{Results and discussion}

Bearing in mind that Croatia has experienced a deeper integration within the EU, this finding can be explained as convergence of prices in Croatia towards the prices within the European Monetary union member countries. Eventually, dummy variable that captures effects on imports from EU membership obtained no statistical significance. Cuestas et al. (2016) provided empirical evidence that most of the Central Eastern European countries converge to a common steady state in inflation dynamics. Since the next step in process of Croatian integration is joining the EMU, there should be no sizable adjustment in prices since the prices seem to be mainly adjusted. Additionally, there is relatively high income elasticity of the import demand in Croatia. Baseline microeconomic theory suggests that demand for primary goods is more elastic to price changes while demand for sophisticated 
products should be more elastic to income changes. Therefore, in the case of Croatia it might be useful to design policy measures towards supporting innovative and sophisticated products. The results of the research are consistent with Hsing (2016) pointing out a need for fiscal discipline in Croatia, as well as with Bošnjak et al. (2018) pointing out the pressures from domestic demand to a current account deficit in Croatia. High income elasticity of import demand and convergence of import prices imply the demand for products of higher quality. Consequently, economic policies in Croatia should be oriented towards production of higher quality products. However, here should be emphasised that this research is based on relative prices vis-à-vis nineteen EMU countries and, while taking into account all trading partners, the results might be different. This is a limitation and further research could be directed towards the effects of relative prices between Croatia and trading partners outside of the EMU.

\section{Conclusions}

There are several conclusions that can be drawn out of the research presented in this paper. Firstly, stand time series approach with OLS estimates revealed average price and income elasticity of the Croatian import demand. The obtained estimates are theoretically consistent and, besides income elasticity, illustrate short-term effects from change in prices to import demand. While taking into account time variation in elasticity of import demand, the results enabled some deeper insights. Income elasticity of import demand has not varied significantly over the observed period while price elasticity of substitution underwent significant changes. At the very beginning of the sample period the price elasticity was above unity. Over time, price elasticity has decreased and at the final state it could not be statistically distinguished from zero. Therefore, the research results supported the main research hypothesis and illustrated convergence of prices between Croatia and the EMU countries. While supporting the research hypothesis and fulfilling the goal and main aim of the paper, the research results revealed changes in elasticity of substitution through different stages of the Croatian path towards the EU. Robust and accurate estimates from state space model with time varying parameters contributes to the existing body of literature and to policy makers in Croatia, while considering the effects of joining the EMU. Eventually, policy makers in Croatia should take into account relatively high income elasticity of import demand and convergence of import prices and support production of higher quality products. 


\section{References}

Andrews, D. W. (1993) "Tests for parameter instability and structural change with unknown change point". Econometrica: Journal of the Econometric Society, Vol. 61, No. 4, pp. 821-856, http://doi.org/10.2307/2951764.

Andrews, D. W., \& Ploberger, W. (1994) “Optimal tests when a nuisance parameter is present only under the alternative". Econometrica: Journal of the Econometric Society, Vol. 62, No. 6, pp. 1383-1414, http://doi.org/10.2307/2951753.

Auboin, M., Borino,F., (2018) "The Falling Elasticity of Global Trade to Economic Activity: Testing the Demand Channel”. CESifo Working Paper No. 7228.

Bilas, V., Bošnjak, M. (2015) "Empirical evidence on Heckscher-Ohlin trade theorem: the case of international trade between Croatia and the rest of the European Union member states", Zbornik radova Ekonomskog fakulteta $u$ Rijeci, časopis za ekonomsku teoriju i praksu-Proceedings of Rijeka Faculty of Economics, Journal of Economics and Business, Vol. 33, No. 1, pp. 103-124.

Bogdan, Ž., Cota, B., Erjavec, N. (2017) "Current Account Balance and Export Performances: Evidence Based on New EU Countries", Zagreb International Review of Economics \& Business, Vol. 20, No. 2, pp. 33-48, http://doi.org/ 10.1515/zireb-2017-0016.

Bošnjak, M. (2019) "Determinants of current account in cases of Serbia and Romania: time-varying parameters approach", South East European Journal of Economics and Business, Vol. 14, No. 1, pp. 21-33, http://doi.org/10.2478/jeb-2019-0004.

Bošnjak, M. (2019a) "Time-varying parameters approach to sustainability of international trade flows: the case of Croatia and Serbia compared", Economic Research-Ekonomska Istraživanja, Vol. 32, No. 1, pp. 3684-3699, http://doi.org /10.1080/1331677X.2019.1674177.

Bošnjak, M., Bilas, V., Novak, I. (2019) "Sustainability of Merchandise Trade Flows between Croatia and Other EU Member States-Panel Cointegration Approach", Panoeconomicus, Vol. 66, No. 1, pp. 113-131, http://doi. org/10.2298/PAN160409022B.

Bošnjak, M., Novak, I., Krišto, A. (2018) "Monetary and absorption approach to explain the Croatian current account", Zbornik radova Ekonomskog fakulteta $u$ Rijeci: časopis za ekonomsku teoriju i praksu, Vol. 36, No. 2, pp. 929-946, http://doi.org/10.18045/zbefri.2018.2.929.

Buturac, G., Mikulić, D., Palić, P. (2019) "Sources of export growth and development of manufacturing industry: empirical evidence from Croatia", Economic Research-Ekonomska istraživanja, Vol. 32, No. 1, pp. 101-127, http://doi.org/10.1080/1331677X.2018.1550003.

Cerasa, A., Buscaglia, D. (2017) "Do the EU countries import at the same price? The case of coffee", Agricultural Economics, Vol. 48, No. 3, pp. 397-408, http://doi.org/10.1111/agec.12342. 
Crucini, M. J., Davis, J. S. (2016) "Distribution capital and the short-and long-run import demand elasticity", Journal of International Economics, Vol. 100, pp. 203-219, http://doi.org/10.1016/j.jinteco.2016.03.010.

Cuestas, J. C., Gil-Alana, L. A., Taylor, K. (2016) "Inflation convergence in Central and Eastern Europe vs. the Eurozone: Non-linearities and long memory", Scottish Journal of Political Economy, Vol. 63, No. 5, pp. 519-538, http://doi. org/10.1111/sjpe.12114.

Çulha, O. Y., Eren, O., Öğünç, F. (2019) Import demand function for Turkey. Central Bank Review. Advanced online publication, http://doi.org/10.1016/j.cbrev.2019. 03.001 .

Dickey, D. A., Fuller W. A. (1979) "Distribution of the Estimators for Autoregressive Time Series with a Unit Root", Journal of American Statistical Association, Vol 74, pp. 427-431.

Elliott, G. Rothenberg, T. J., Stock, J. H. (1996) "Efficient Tests for an Autoregressive Unit Root", Econometrica, Vol. 64, No. 4, pp. 813-836.

Engle, R. F., Granger, C. W. (1987) "Co-integration and error correction: representation, estimation, and testing", Econometrica: journal of the Econometric Society, pp. 251-276, http://doi.org/10.2307/1913236.

Ghodsi, M., Grübler, J., Stehrer, R. (2016) Import demand elasticity's revisited. Vienna Institute for International Economic Studies.

Hałka, A., Leszczyńska-Paczesna, A. (2019) "Price convergence in the European Union-What has changed?", Economic Modelling, Vol. 79, pp. 226-241, http:// doi.org/10.1016/j.econmod.2018.11.002.

Harvey, A. C., (1991) Forecasting, Structural Time Series Models and the Kalman Filter. CambridgeUniversityPress.

Hsing, Y. (2016) "Impacts of Government Debt, the Exchange Rate and Other Macroeconomic Variables on Aggregate Output in Croatia", Managing Global Transitions: International Research Journal, Vol. 14, No. 3, pp. 223-231.

Kalman, R. E. (1960) "A new approach to linear filtering and prediction problems", Trans. ASME J.Basic Eng., Vol. 82, pp. 35-45.

Kurtovic, S., Blerim, H., Nehat, M., (2016) Bilateral Trade Elasticity: B\&H versus its seven trade partners, MPRA Paper No. 72297.

Kwiatkowski, D., Phillips, P., Schmidt, P., Shin, Y. (1992) "Testing the Null Hypothesis of Stationarity Against the Alternatives of a Unit Root: How Sure Are We That Economic Time Series Have a Unit Root?", Journal of Econometrics, Vol. 54, pp. 159-178.

Mervar, A. (1994) "Estimates of the traditional export and import demand functions in the case of Croatia", Croatian economic survey, Vol. 1, pp. 79-93.

Mikulić, D., Lovrinčević, Z. (2018) "The import content of Croatian economic sectors and final demand", Economic research-Ekonomska istraživanja, Vol. 31, No. 1, pp. 2003-2023, http://doi.org/10.1080/1331677X.2018.1480967. 
Phillips, P. C. B., Perron, P. (1988) “Testing for a unit root in time series regression”, Biometrika, Vol. 75, pp. 335-346.

Ranilović, N. (2017) "The effects of economic integration on Croatian merchandise trade: a gravity model study", Comparative Economic Studies, Vol. 59, No. 3, pp. 382-404, http://doi.org/10.1057/s41294-017-0032-6.

Zhang, H., Kuuluvainen, J., Lin, Y., Gao, P., Yang, H. (2017) "Cointegration in China's log import demand: Price endogeneity and structural change", Journal of Forest Economics, Vol. 27, pp. 99-109, http://doi.org/10.1016/j.jfe.2017. 03.003 . 


\title{
Vremenski promjenjivi parametri potražnje za uvozom u Republici Hrvatskoj
}

\author{
Mile Bošnjak ${ }^{1}$, Vlata Bilas ${ }^{2}$, Domagoj Račićc ${ }^{3}$
}

\begin{abstract}
Sažetak
Ovaj rad ima za cilj ispitati elastičnost potražnje za uvozom u Republici Hrvatskoj na promjene u dohotku i relativnim cijenama, istovremeno dopuštajući vremensko variranje parametara potražnje za uvozom. Uzorak podataka sastoji se od kvartalnih podataka vremenskih serija između prvog kvartala 2000. i trećeg kvartala 2018. godine. Korištenjem modela prostora stanja s vremenski različitim parametrima dobivene su i testirane procjene pristupa. Rezultati su pokazali trajnu $i$ visoku dohodovnu elastičnost uvozne potražnje u Hrvatskoj. Međutim, uloga relativnih cijena promijenila se u promatranom razdoblju i na kraju se ne može razlikovati od nule. Rezultati ovog istraživanja podržali su hipotezu konvergencije cijena u Hrvatskoj prema cijenama u zemljama članicama Europske monetarne unije. Nadalje, rezultati nisu pokazali značajan utjecaj na potražnju za uvozom u Republici Hrvatskoj nakon ulaska Hrvatske u Europsku uniju. Rezultati istraživanja pokazuju da bi, zbog relativno visoke dohodovne elastičnosti uvozne potražnje i konvergencije uvoznih cijena, trebalo poticati proizvodnju inovativnih $i$ sofisticiranih proizvoda.
\end{abstract}

Ključne riječi: potražnja za uvozom, dohodak, relativne cijene, Kalman filter, Republika Hrvatska

JEL klasifikacija: C13, C51, F17, F14

${ }^{1}$ Docent, Sveučilište u Zagrebu, Ekonomski fakultet, Trg J. F. Kennedyja 6, 10000 Zagreb, Hrvatska. Znanstveni interes: međunarodna ekonomija, nelinearna ekonometrija, primijenjena ekonometrija, neuronske mreže. Tel.: +38512330 374.E-mail: mbosnjak1@net.efzg.hr.Web stranica: https://orcid.org/0000-0002-7663-198X.

${ }^{2}$ Redoviti profesor, Sveučilište u Zagrebu, Ekonomski fakultet, Trg J. F. Kennedyja 6, 10000 Zagreb, Hrvatska. Znanstveni interes: međunarodna ekonomija, regionalne integracije. Tel.: +3851 2330374. E-mail: vnbilas@efzg.hr. Web stranica: https://orcid.org/0000-0002-90216651 .

3 Doktorand, Sveučilište Josipa Jurja Strossmayera u Osijeku, Ekonomski fakultet, Trg Lj. Gaja 7 , 31000 Osijek, Hrvatska. Znanstveni interes: mreže znanja, konkurentnost, politička ekonomija. E-mail: domagoj.racic@mrezaznanja.hr.Web stranica: https://orcid.org/0000-0001-8380-9996. 
Mile Bošnjak, Vlata Bilas, Domagoj Račić • Time-varying parameters of Croatian...

\section{Appendices}

Table A1: Descriptive statistics of the observed series

\begin{tabular}{|l|c|c|c|}
\hline & M & Y & REER \\
\hline Min. & 9.628 & 10.64 & 4.459 \\
\hline 1st Qu. & 10.258 & 11.02 & 4.526 \\
\hline Median & 10.407 & 11.30 & 4.565 \\
\hline Mean & 10.364 & 11.18 & 4.556 \\
\hline 3rd Qu. & 10.515 & 11.32 & 4.576 \\
\hline Max. & 10.772 & 11.45 & 4.615 \\
\hline
\end{tabular}

Source: Authors' calculations

Table A2: Engle-Granger cointegration test results

\begin{tabular}{|l|c|c|c|c|}
\hline Dependent variable & tau-statistic & $\mathrm{p}$ - value & z-statistic & $\mathrm{p}$ - value \\
\hline $\log (M)$ & -2.945732 & 0.2815 & -11.13361 & 0.5053 \\
\hline $\log ($ REER $)$ & -3.315311 & 0.1529 & -15.94007 & 0.2440 \\
\hline $\log (Y)$ & -3.193414 & 0.1897 & -14.37320 & 0.3161 \\
\hline
\end{tabular}

Source: own estimates

Figure A1: Development of the observed series in (natural) log levels

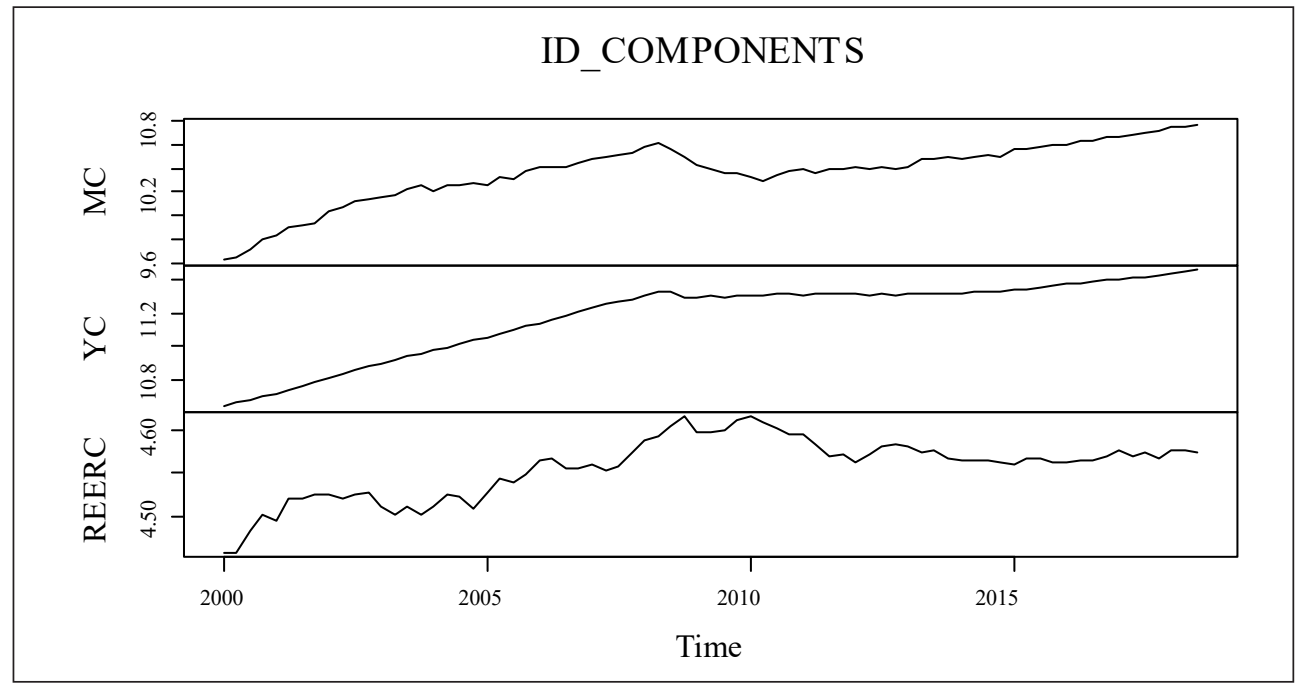

Source: Authors' calculations 
Figure A2: Share of imports to GDP

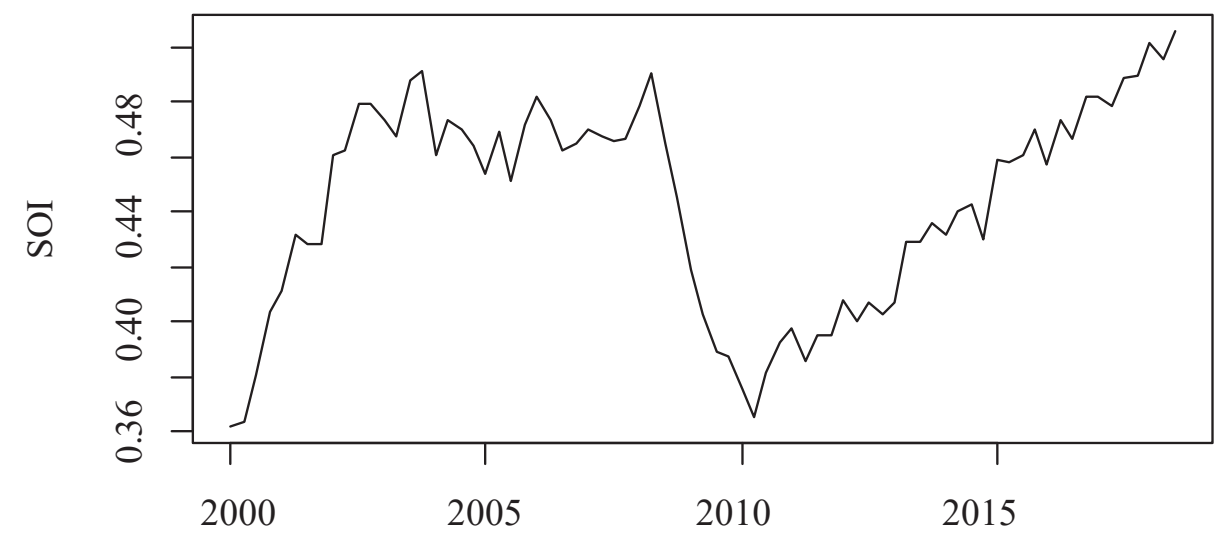

Time

Figure A3: TV estimates of constant term: the case of Croatia

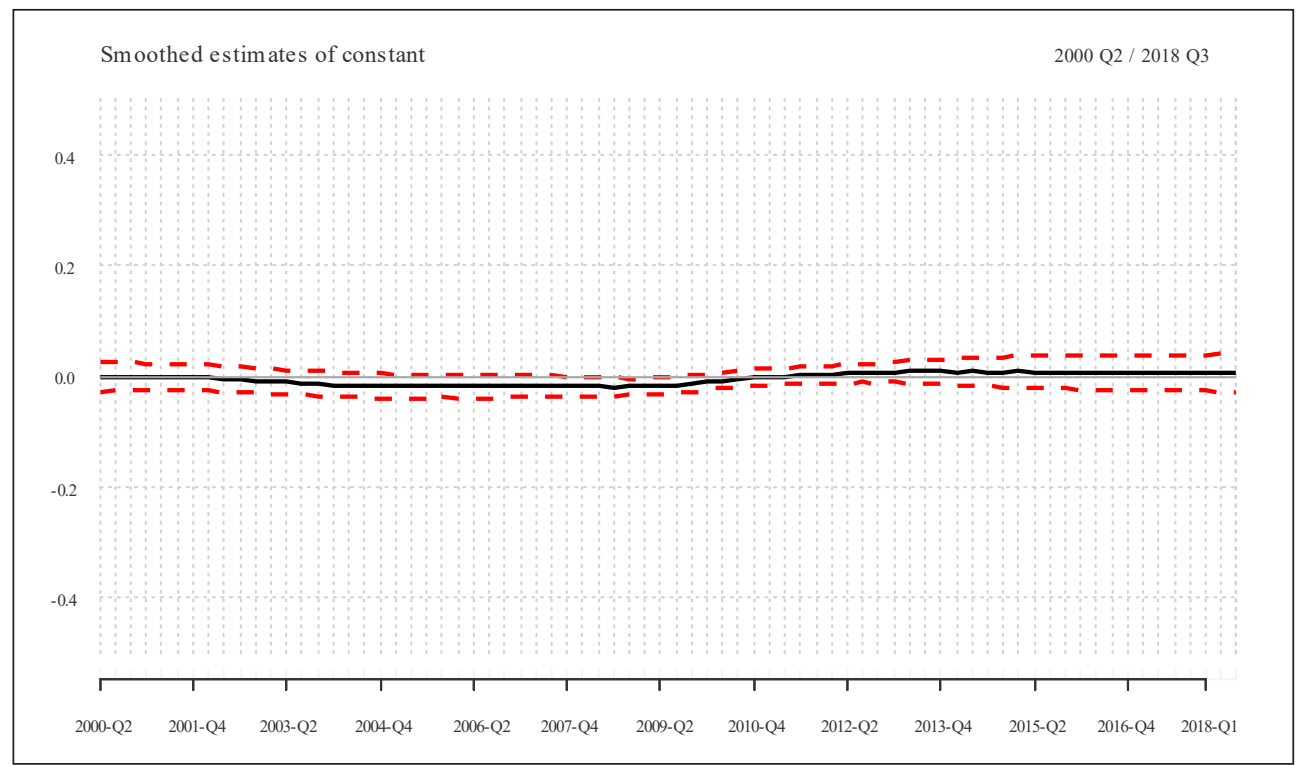

Source: Authors' calculations 
Mile Bošnjak, Vlata Bilas, Domagoj Račić • Time-varying parameters of Croatian...

Figure A4: TV estimates of income elasticity of import demand: the case of Croatia

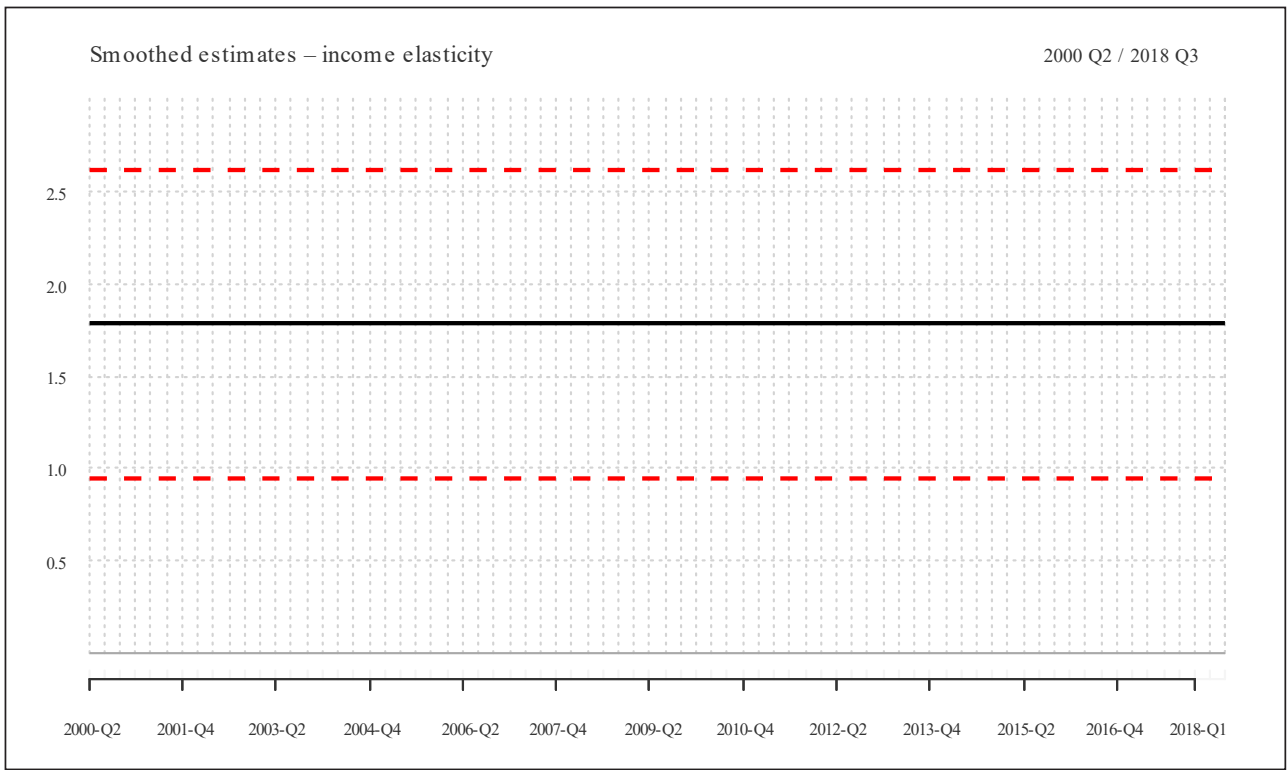

Source: Authors' calculations

Figure A5: TV estimates of price elasticity of import demand: the case of Croatia

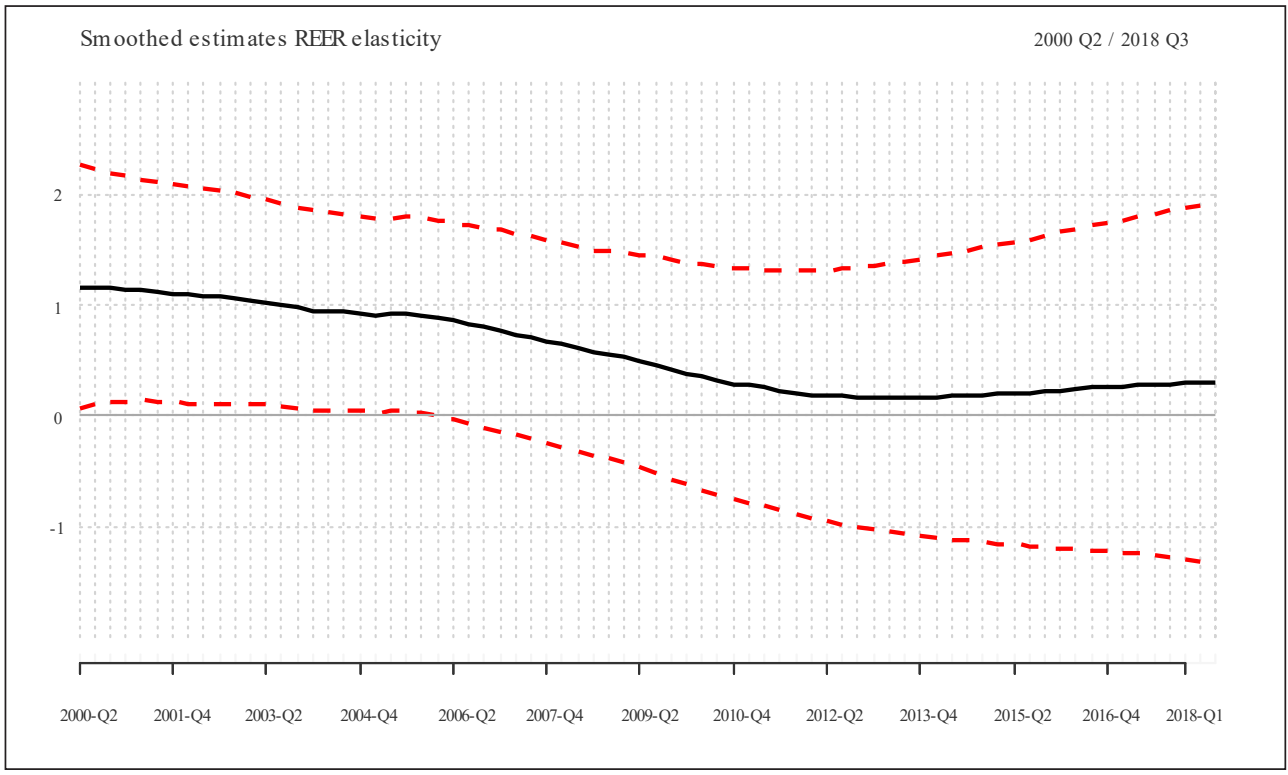

Source: Authors' calculations 
Figure A6: TV estimates of EU membership effects: the case of Croatia

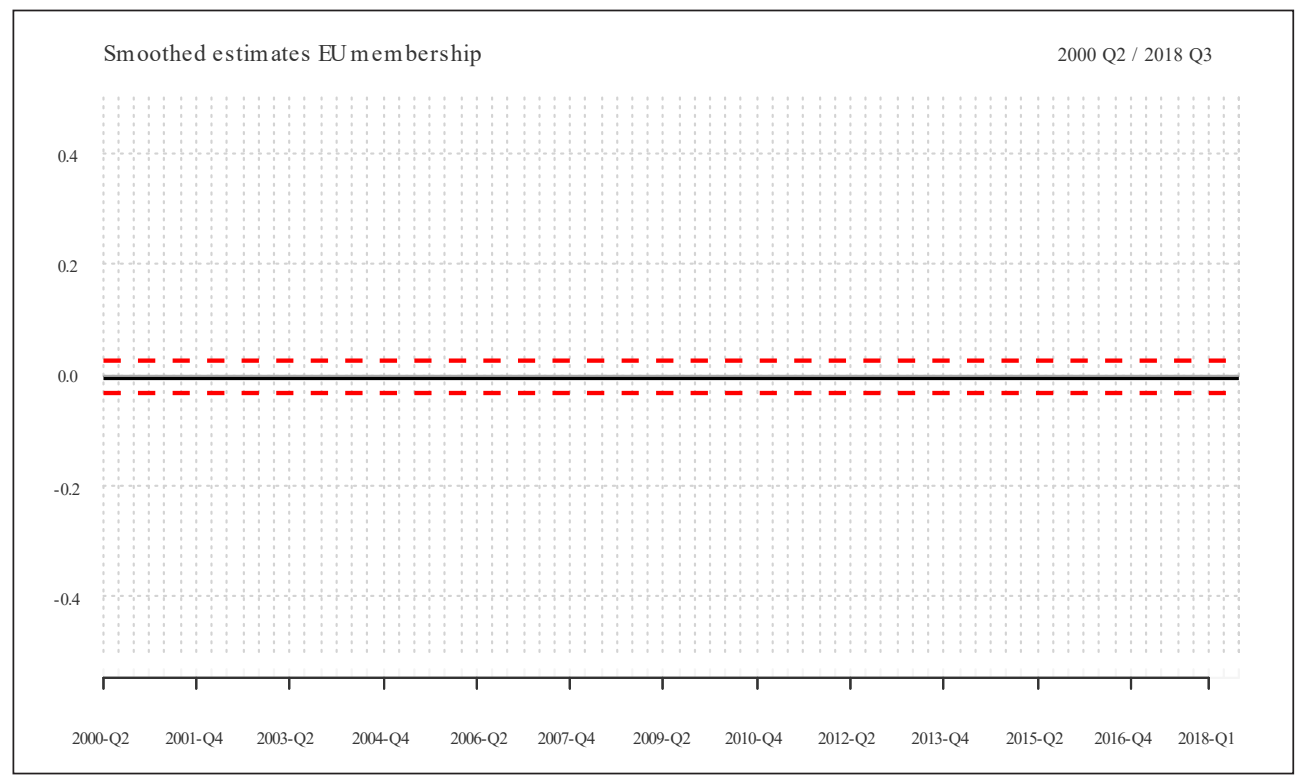

Source: Authors' calculations 